\title{
IAMJ
}

INTERNATIONAL

AYURVEDIC

MEDICAL JOURNAL

Review Article

ISSN: 2320-5091

Impact Factor: 6.719

\section{ROLE OF CHAYA AND PRABHA TO MAINTAIN SKIN COLOR}

\section{Niketa Soni $^{1}$, Rajesh Kumar Sharma ${ }^{2}$, Dinesh Chandra Sharma ${ }^{3}$}

${ }^{1}$ P.G. Scholar, P.G. Department of Kriya Sharir, DSRRAU, Jodhpur, Rajasthan, India

${ }^{2}$ Professor \& H.O.D., P.G. Department of Kriya Sharir, DSRRAU, Jodhpur, Rajasthan, India

${ }^{3}$ Associate Professor, P.G. Department of Kriya Sharir, DSRRAU, Jodhpur, Rajasthan, India

Corresponding Author: nikitasoni018@gmail.com

\section{https://doi.org/10.46607/iamj0509062021}

(Published Online: June 2021)

Open Access

(C) International Ayurvedic Medical Journal, India 2021

Article Received: 03/05/2021 - Peer Reviewed: 04/05/2021 - Accepted for Publication: 05/05/2021

Check for updates

\section{ABSTRACT}

According to Ayurveda beauty is determined such as Varna (Color), Prabha (Radiance) and Chaya (Personality) and depends on many other factors like prakriti, sara, doshas etc. These factors are the innate entities of beauty and represent all the parameters for healthy and radiant skin. Beauty reflects the equilibrium of all the dhatus (tissues), doshas \& acts as a barometer of individual's health. This paper aimed to investigate the concept of Chaya and Prabha by exploring the material in classical texts in Ayurveda. Varna incorporates the entities like color, texture, luster, appearance and nourishment (plumpness). Dermatological parameters such as skin hydration, pigmentation, sensitivity and wrinkling come under the extent of Varna. Appearance, built, color, radiance and overall beauty are the components of Chaya (Personality), Varna and Prabha are contributory factors of Chaya. According to modern science, three main pigments i.e. Melanin, Carotene and Hemoglobin are considered for the skin color. The color, complexion and appearance of the individuals vary greatly. This varna is affected by many factors before and after birth of human life.

Keywords: Chaya, Prabha, Varna, Melanin.

\section{INTRODUCTION}

The particular 'Chaya' affect the outcome of health and socio-economic status. It is also essential to know whether individuals with certain Chayas better immune against diseases are so as to enjoy the lon- gevity and fortunes of the life. The word 'Chaya' denotes skin complexion, Skin complexion and color of a person mainly depend upon parents. According to Acharya Kashyapa equilibrium of all the dhatus is 
the root cause for strength, complexion, vigor, intellect and happiness The disrupt state of the same result in ailments. ${ }^{1}$ Therefore Varna is also considered as one of the criteria for examining the Dhatu Samya. $^{2}$ In Charak samhita, Acharya in Indriyasthana describes about the prognostic symptoms, in which Varna, as it can be directly observed has given more magnitude in postulating the lifespan of an individual. ${ }^{3}$ According to Charaka, The word Varna is not intended to convey the color and complexion, but for all these distinctive attributes which can be recognized by the eyes. ${ }^{4}$

Types of Chaya- 5 (originate from Panchmahabhuta) ${ }^{5}$ Nabhasi, Vayaviya, Aagneya, Ambhasi, Parthiva,

Types of Prabha - 7 (originate from Tejas tatva) ${ }^{6}$ Rakta, Pita, Sita, Shyava, Harita, Pandur, Asita,

\section{Skin Complexion Evaluation}

The skin complexion evaluation can be done by using C.L.B.T. method which is based upon a visual sensory analysis of the four following descriptors (Chaya vividhlaxana) color, luminosity, brightness and transparency of the skin of the face.

1. Decrease in the "Yellow" color can be interpreted as an effect "looks good" (complexion was less yellowish) (Shudhavaiduryavimala ambhasi).

2. Decrease in the "Olive" color can also be interpreted as an effect "looks good" (less of a greenish-olive complexion) (Shudhavaiduryavimala ambhasi).

3. Increase in the "Pink" color is interpreted as "the skin looks healthier" (Vishuddhrakta tvaagneyi).

4. Increase in the "Brightness" means that the homogeneity of the skin was improved. Increase in the "Transparency" means that the skin seems to be thinner. (Vishuddhrakta tvaagneyi).

5. Whereas an increase in the "Luminosity" is related to a more pronounced reflection of the light by the skin (aagneyi diptaabha). ${ }^{7}$

Blood oxygenation state is related to health status and affects skin color. In women, increased sex hormone levels are associated with increased skin vascularisation and vasodilatory response, which arterializes the blood in the skin.
Skin color is a blend resulting from

Skin chromophores - Red (oxyhaemoglobin) (Rakta tvaagneyi)

Blue (deoxygenated hemoglobin) (Naabhasi neela \& shyavaaruna ya tu vaayvi, Yellow orange (carotene, an exogenous pigment) (Vaidurya ch ambhasi) Brown (melanin) (Shyama ch parthivi).

\section{PRABHA}

Prabha denotes radiance or luminance which is due to greater reflection of light from the skin,

blood oxygenation, increased vascularisation, and also physiological health. Prabha can also be considered as AURA. The human aura may be described as a fine, ethereal radiation or emanation similar to that of electromagnetic field (EM) surrounding each and every

living being which can be observed only by trained eyes. Aura not only made from color and energy, but also has shape or dimensions. The Aura energy system has the seven colors similar

to the band of colors in the rainbow, that is, VIBGYOR (Violet, Indigo, Blue, Green, Yellow,

Orange and Red) and each color is associated with seven Chakras. Seven

types of Prabha may have connection with seven Chakras and the colors of AURA.

\section{VARNOTPATTI-}

The physiological phenomenon of Varna utpatti (formation of Varna) is basically maintained by many factors, some contribute to the formation of Varna in Garbhavastha and some factors contribute in the process after birth and later stage of life. As per Mansanumasika Garbha Vriddhi Krama the Varnautpatti Kala is considered to be as 6th month by almost all the Scholars. In the 6th month the pregnant lady suffers from Varna hani. ${ }^{8}$ So Varnotpatti can be differentiated into two main categories.

\section{A. Factors contributing to the formation of Varna in Foetal life. \\ Role of Mahabhuta; Role of Shukra; Garbhakar bha- vas; Desh, kula, jati}




\section{B. Factor contributing to the process of varnot- patti after birth.}

- Jatharagni; Dosha, dhatu \& mala; Oja; Vaya

Prakriti and Complexion

Prakriti (Temperament) of the individuals determines these entities. 3 major types of Prakriti (Temperaments) have been dealt in Ayurveda. Individuals of Vata Prakriti will have a dull complexion with rough texture, Individual of Kapha Prakriti will have a bright and fair complexion, smooth and unctuous skin. Hence the novel concept of beauty dealt in Ayurveda is highly substantial.

The total health of the skin is reported by its texture, color, tone, lustre, complexion etc. Complexion means normal appearance of the skin on a person's face. Texture is the quality of something that can be decided by touch, something is rough or smooth; soft or hard. Lustre shiny. In Ayurveda, terms like Kanti, Prabha, Chhaya, Varna etc. are used regarding the subject.

Varna and Prabha are the contributory factors of Chaya.

\section{MELANIN}

In humans, melanin exists as three forms: eumelanin (which is subdivided further into black and brown forms), pheomelanin, and neuromelanin. In its various forms, melanin fulfills a variety of biological functions, including skin and hair pigmentation and photoprotection of the skin and eye.

Pigmentation of the skin results from the accumulation of melanin-containing melanosomes in the basal layer of the epidermis. Differences in skin pigmentation result both from the relative ratio of eumelanin (brown black) to pheomelanin (yellow-red), as well as the number of melanosomes within melanocytes. Pheomelanin accounts for the pinkish skin constituting the lips, nipples, vagina, and glans of the penis. In general, lightly pigmented skin tends to contain melanocytes with clusters of two to three melanosomes, whereas darkly pigmented skin tends to contain individual melanosomes which can melanize neighboring keratinocytes more readily. The overall melanin density correlates with the darkness of skin.

\section{DISCUSSION}

From the above description it is clear that skin color of a person does not depend on single factor. The process of formation of skin color starts from Garbhavastha and it continues after birth. So, there are certain factors which involve in Varnotpatti during Garbhavastha such as Mahabhuta, Shukra, Triguna, Garbhotpadak Bhava, Psychology of mother and on Desa, Kula and Jati. There are also some other factors which participate in process of Varnotpatti after birth such as Jathragni, Ahara, Aharvidhi, Dosa and Dhatu. Modern medical science also says that the Desa affects the Varna (complexion) of a person. Area which receives higher amount of ultraviolet radiation, generally located closer to the equator, tend to have darker skinned populations. Areas that have lower concentration of ultraviolet radiation which is reflected in lighter skinned population. Natural skinned color can also darken as a result of tanning due to exposure to sunlight. Hence it proves that distribution of melanin is according to the solar intensity hence the concept of Desha affecting the Varna. ${ }^{9}$ As the skin color is mainly dependent upon genes, nothing more can be done but complexion and radiance of the skin can be maintained or increased by taking proper care as protection from excess sunlight, frequent cleaning etc.

\section{CONCLUSION}

Every person has particular skin color and complexion. Genetic factor is important in determination of an individual's basic skin color Varna of an individual depends on various factors like prakriti, genetic, doshas and dhatus. Formation of skin color starts with the Garbhavastha (pregnancy) which is discussed above. According to modern medical science also skin color in human beings is affected by many factors but the most important substance is the pigment melanin. If the melanin is more in the skin the solar radiation is absorbed more and it leads to DNA damage to the skin and body naturally combats and seeks to repair damage and protect the skin by releasing further melanin. The skin color of people with light skin is determined mainly by the hemoglobin 
circulating in the veins of the dermis. The red color underlying the skin becomes more visible, especially in the face, when, as consequences of physical exercise or the stimulation of the nervous system (anger, fear) arterioles dilate.

\section{REFERENCES}

1. Kashyapa, Sutrasthana, 27/17, Sharma Hemaraja, Kashyapa Samhita, Chaukhamba Sanskrit Sansthana, Varanasi, 2009.

2. Agnivesha, Charak Samhita, Sutrasthana 24/4, Ayurved Dipika Commentary of Chakrapanidatta, edited byVaidya Yadavji Trikamji Acharya, Chaukhambha Sanskrit Sansthana, edition 2000.

3. Charak Samhita, Indriya Sthana, $1 / 11$, edited \& translated by Pt. Kashinath Shastri, Chaukhambha Sanskrit Sansthana.

4. Charak Samhita, Indriya Sthana, $1 / 11$, edited \& translated by Pt.Kashinath Shastri, Chaukhambha Sanskrit Sansthana, edition,2000.

5. Charak Samhita, Indriya Sthana, $7 / 10$, edited \& translated by Pt.Kashinath Shastri, Chaukhambha Sanskrit Sansthana, edition,2014.

6. Charak Samhita, Indriya Sthana, 7/14-15, edited \& translated by Pt.Kashinath Shastri, Chaukhambha Sanskrit Sansthana, edition,2014.

7. Périn FA, Saetun KA, Pungpod PA, Pram-On MO, Périn VE,Aroonrat NI, Siritemboon C, Dhavan

8. V. A new method for thein vivo visual evaluation of the radiance of the Asian skin complexion.

9. Charak Samhita, Sharirasthana, 4/22, edited \& translated by Pt. Kashinath Shastri, Chaukhambha Sanskrit Sansthana, edition,2000.

10. Norton, H.L.; Kittles, R.A. et al. Genetic Evidence for the Convergent Evolution of light skin in Europeans and east Asians, Molecular biology and evolution.

\section{Source of Support: Nil}

\section{Conflict of Interest: None Declared}

How to cite this URL: Niketa Soni et al: Role Of Chaya And Prabha To Maintain Skin Color. International Ayurvedic Medical Journal \{online\} 2021 \{cited June, 2021\} Available from:

http://www.iamj.in/posts/images/upload/1190_1193.pdf 